\title{
Reading interest and information needs of persons with visual impairment in Nigeria
}

\author{
'Niran Adetoro' \\ Department of Library and Information Science, Tai Solarin University of Education, ljebu-Ode, Nigeria. \\ niranadetoro@yahoo.com
}

\begin{abstract}
Received 17 May 2010
Accepted 5 July 2010

Information materials can only become usable to persons with visual impairment when they are transcribed into alternative formats. Over time, the transcription and provision of alternative formats in Nigeria by libraries has not been based on users' reading interest and information needs. This study delves into the reading interests and information needs of persons with visual impairment in Nigeria. Survey research design was adopted and the study purposively focused on southwestern Nigeria. Using stratified proportionate random sampling techniques, data was gathered by questionnaires namely the Visually Impaired Adult Questionnaire VIAQ $(=0.75)$ and Visually Impaired Student Questionnaire VISQ $(=0.78)$ from fourteen selected libraries stratified into non-governmental, public, tertiary institutions and secondary schools. Of the 563 copies of the questionnaire that were administered, $40 \mathrm{I}$ (7I.3\%) were successfully completed and used for the study. The study found that adults with visual impairment had high reading interests in religious, business, and entertainment materials, among others. Secondary school respondents had high reading interest in art subjects, reference materials, manuals and animal story materials. Both respondents showed high information needs in expected and relevant areas. Braille materials (58.3\%) are the most preferred source of information generally. Adult respondents preferred Braille (72.4\%), while the secondary school respondents preferred Talking books/audio recordings (55\%). Transcription and provision of information materials for the visually impaired through libraries should be based on knowledge of their reading interest and information needs.
\end{abstract}

Keywords: Reading interest; information needs; persons with visual impairment; Nigeria

\section{Introduction}

In virtually all countries, it has been realised that persons with visual impairment (PVI) need information as much as sighted persons. Nigeria has also come to this realisation. Persons with visual impairment need information to function effectively as human beings; this is why the advocacy for equal access to information for PVI has been on the ascendancy in recent times. The Royal National Institute for the Blind RNIB (2006) describes persons with visual impairment as people with irretrievable loss of sight. These include persons with partial sightedness, low vision and total blindness (Arditi and Rosenthal 1998).

Studies such as Horten and Horten (1995) and Byrne et al., (1990) found that the reading interest of persons with visual impairment are as varied and similar as those of the sighted. The reading interests of persons with visual impairment also vary in accordance with age, status and stage attained in life. Persons with visual impairment ranging from primary school pupils, high school students, undergraduates, and adults to the elderly, all have different reading interests (Kimmins 1996; Nielson 2005). Just like the sighted, the range of what persons with visual impairment want to read range from adventure to history, mystery, politics, biography, natural sciences, sports, romance, religion, etc. In the same vein, the information needs of persons with visual impairment, just like the sighted, are supposed to portray their peculiarities as well as the information sources consulted. Regardless of status, people's information needs are sourced and selected from their environment. Adetoro (2004) stated that persons with visual impairment like any social group need information to reduce uncertainty, define and solve problems and ultimately for individual growth and survival.

From the foregoing, it is evident that persons with visual impairment need information and therefore it is essential that providers and producers of information for persons with visual impairment in Nigeria should establish their reading interests and information needs for improved service provision. For ease of analysis, this paper divides the respondents of the study into two groups: the adult respondents and the secondary school student respondents. Consequently, the reading interests and information needs of the adult persons with visual impairment were examined separately from those of the secondary school students. This is because the two categories do not share the same reading interests and information needs.

I. 'Niran Adetoro (PhD) is a senior lecturer in the Department of Library and Information Science at Tai Solarin University of Education, ljebu-Ode, Nigeria. 


\section{Statement of the problem}

Libraries and information centres for persons with visual impairment in Nigeria have not been providing information materials geared towards their reading interests and information needs. Materials (alternative format) transcription and provision by stakeholders which include public libraries, non-governmental organisations (NGOs) libraries, libraries for the visually impaired including government operated, have not taken them into consideration. Rather than being based on empirical evidence, material provision is probably a function of what is available and not the request of the persons with visual impairment, hence the discontent over the years towards the provision of information services. While the demand for information materials in alternative format by persons with visual impairment is increasing, supply has remained inadequate. This study therefore investigates the reading interests and information needs of persons with visual impairment in selected libraries in southwestern Nigeria.

The specific objectivesof this study were to:

I. Determine the reading interest of persons with visual impairment in the selected libraries.

2. Find out the information needs of persons with visual impairment in the selected libraries.

3. Determine the sources of information consulted by persons with visual impairment in the selected libraries.

\section{Literature Review}

It is generally believed that because persons with visual impairment have the same human composition as sighted people; their reading interest and information needs are likely to be similar. Thus, Owen (2000) claimed that persons with visual impairment have the same library and information needs as everyone else except that they may require some adaptations. Information services to persons with visual impairment definitely require adaptations in order to satisfy the needs of the visually impaired.

Atinmo (1999) found that the reading interests of persons with visual disabilities in Nigeria are varied just like those of sighted individuals. Visually impaired library users' reading interests in Norway vary as they preferred textbooks, reference works, fiction, non-fiction, in-print and electronic materials (Horten and Horten, 1995). Persons with visual impairment need factual and recreational reading, educational materials, encyclopedias, directories and other kinds of publication used by sighted people, but unlike the sighted, they need appropriate formats or auxiliary aids to help them access their reading interests (Chartered Institute or Library and Information Professionals (CILIP) 2005). A study conducted over radio signals (Davis 2005) found that blind people are interested in reading daily newspapers, magazines and other periodicals; supermarket, drugstore and departmental store advertisements as well as community events, breaking state, national and world news.

Visually impaired children in Canada often choose to read if provided with books that are at an appropriate reading level and are about their personal areas of interest (Canadian National Institute for the Blind (CNIB) 2005). A study of the homebound elderly by Nielson (2005) found that the range of reading interests of the elderly visually impaired is as broad as those visiting libraries in person. Many of them, he claimed, have high concentration on reading and their reading interest centres on natural science and ancient history.

CNIB (2005) found that children have an interest in poems and short stories, while a similar study (Bachmutskaya \& Yankova 1996) found that Russian children have an interest in democracy, humanism, history, foreign and Russian fiction as well as leisure materials. Studies on the information needs of specific user groups are central to information behaviour research. These studies have examined the information needs of user groups in a variety of contexts. To meet the information needs of the disabled persons, Moahi and Monau (1993) advised that services should be appropriate for the type of disability that affects the person to whom services are meant. The bottom line for information needs studies is that they assist organisations to put in place resources that will meet users' needs and enhance organisational objectives. (Oyediran-Tidings 2004).

Hopkins (1989), Watson-Boone (1994) Shahzad (2007) as well as Tahir, Mahmad and Shafrique (2008) investigated the information needs of scientists, social scientists and humanists. Information needs of undergraduates had been examined in Eskola (1998) and Fiankor and Adams (2004).

In Nigeria, Edem (1993) investigated the information needs of journalists; Popoola (1996) studied civil servants while Adetoro (2004) examined commercial motorcycle operators. Mabawonku (2004) studied the information needs and use of artisans and found that professional/job related information, health information, politics/governmental information and financial related information were the most required.

The literature above points to the significance of knowing the reading interest and information needs of person with visual impairment before information materials in alternative format are provided. In order to ensure that services and facilities of libraries for the visually impaired are appropriate, visually impaired users should be consulted about their reading interests and information needs at least every two years (CILIP 2005). 


\section{Methodology}

Descriptive survey research design was adopted for the study. Fourteen libraries were selected based on the population of their visually impaired users provided with information materials in alternative formats. The southwest geo-political zone of Nigeria was specifically chosen for the study, because it is the only zone that has libraries that cater for persons with visual impairment users and have reasonable numbers of materials worth studying. Through a preliminary study, the study population was found to be 563 persons with visual impairment who are also information users in the selected libraries.

The selected libraries included two non-governmental (NGO) libraries, four public libraries, two tertiary institution libraries and six (6) secondary school libraries. Two sets of questionnaires namely Reading Interest Adult Questionnaire RIAQ $(=0.73)$ for the adult respondents in all the libraries except secondary school libraries and Reading Interest Students Questionnaire RISQ $(=0.78)$, which gathered information from the respondents in secondary schools, were used for data collection.

With the assistance of the librarians in charge of the libraries, questionnaires were administered directly to the respondents. They were read to them and their responses were indicated directly on the questionnaires by the researcher and his trained assistants.

Of the 563 copies of the questionnaire administered, $40 \mathrm{I}$ which represent (7I.3\%) of the population, were successfully completed and used for the study. Frequency counts and percentages as well as mean and standard deviation were used for analysis.

\section{Results}

Data gathered showed that male respondents were 256 (67.1\%) while females were 136 (32.9\%), 104 (26\%) were students in secondary school while 297 (74\%) were adults who were out of school. Most of the respondents were single 303 (75.5\%), while 98 (24.4\%) were married. The data also showed that $224(54.3 \%)$ of the respondents were totally blind while 177 (45.7\%) were partially sighted.

Table I Reading interests of adult persons with visual impairment $(\mathrm{N}=297)$

\begin{tabular}{|c|c|c|}
\hline Reading Interest & Mean & $\begin{array}{l}\text { Standard } \\
\text { Deviation }\end{array}$ \\
\hline Religious materials on general and specific aspect of faith & 3.62 & 0.72 \\
\hline Stories or textbooks about business and how to succeed in business & 3.40 & 0.89 \\
\hline General entertainment materials such as magazines and periodicals & 3.40 & 0.84 \\
\hline Manuals that teach how to do things & 3.39 & 0.86 \\
\hline General and specific reference materials & 3.30 & 0.94 \\
\hline Biographical accounts of individuals of achievements & 3.23 & 1.02 \\
\hline Works of poetry that stimulate reasoning. & 3.05 & 0.90 \\
\hline Dramas / Plays with good plots & 2.98 & 0.91 \\
\hline Works on security and safety and about security of lives and property & 2.95 & 0.74 \\
\hline Works that stimulates entertainment and amusement /Humour stories & 2.88 & 1.06 \\
\hline Works/ textbooks related to the arts such history, literary studies and languages. & 2.86 & 0.92 \\
\hline Books/stories about romance and love live of people & 2.82 & 1.10 \\
\hline Tales/stories describing how to get to places, how to make journeys to important places of interest. & 2.78 & 1.07 \\
\hline Accounts of events, things and happenings which has no cause or origin, works of mystery which cannot be explained. & 2.77 & I.0I \\
\hline History text for leisure and academic purposes & 2.71 & 1.19 \\
\hline Unusual and exciting tales of dangerous experiences, events or occurrence/adventure stories & 2.65 & 0.97 \\
\hline Works or textbook on social sciences such as sociology, economics, political science etc. & 2.54 & 0.87 \\
\hline General sporting events and sports personalities or a particular sports report & 2.54 & 1.06 \\
\hline Detective stories that help unravel difficult crime. & 2.52 & 1.02 \\
\hline Works /textbook on technology, technological feats and happenings. & 2.51 & 1.10 \\
\hline News or stories about your local or immediate community events/happenings & 2.49 & 1.15 \\
\hline Political stories, political events and writings about politics locally or globally & 2.18 & 1.22 \\
\hline Natural science works or textbooks such as physics, chemistry and biology, scientific events and discoveries & 1.86 & 1.00 \\
\hline
\end{tabular}


Table 2 Reading interest of secondary school persons with visual impairment $(\mathrm{N}=104)$

\begin{tabular}{|c|c|c|}
\hline Reading Interest & Mean & Standard Deviation \\
\hline Materials or textbooks on arts subjects such as history, government and literature & 3.27 & 0.84 \\
\hline Reference materials such as dictionaries, encyclopedias, directories, etc & 3.04 & 1.06 \\
\hline Manuals/stories that describe how to do things & 3.04 & 0.95 \\
\hline Stories about animals or specific kinds of animal. & 2.91 & 1.06 \\
\hline Stories on family life and about families. & 2.91 & 1.01 \\
\hline Stories on school activities and the challenges students face at school. & 2.86 & 1.00 \\
\hline Funny or amusing and entertaining stories/humour stories. & 2.82 & 0.99 \\
\hline General or specific sporting events, achievement or stories. & 2.77 & 1.29 \\
\hline Stories about the life of people who have achieved/biographies. & 2.70 & 1.02 \\
\hline General unreal stories and fantasies. & 2.67 & 1.13 \\
\hline Books/textbooks on subjects such as economics, commerce and business management. & 2.65 & 1.10 \\
\hline An account of an usual and exciting or dangerous experience or events, feat or occurrence/adventures stories. & 2.56 & 1.12 \\
\hline Poems for relaxation and for classroom work. & 2.51 & 1.16 \\
\hline Tales of events, things or happenings which have no trace or origin/mystery stories & 2.47 & 1.01 \\
\hline Historical literature or stories describing unreal or imaginary events or people/ Historical fiction. & 2.33 & 1.10 \\
\hline Tales on a particular war or about wars/war stories & 2.10 & 1.04 \\
\hline Stories describing unreal scientific event(s) or people / science fiction & 1.80 & 0.98 \\
\hline Books or textbooks on natural science subject such physics, chemistry and biology. & 1.52 & 0.91 \\
\hline
\end{tabular}

5.1 Reading interests of persons with visual impairment in the selected libraries

The respondents were asked to indicate their reading interests for leisure reading and academic purposes. The reading interest of the respondents were analysed in the two categories in which the respondents were classified i.e. adult respondents and secondary school student respondents; both with different reading interests. The result showed that adult respondents have their reading interest rated high in religious books and materials on general and specific aspects of faith $(x=3.62$; SD $=0.82)$, business and entrepreneurial books and materials on how to succeed in business $(x=3.40$; $S D=0.89)$, Entertainment materials such as magazines and periodicals $(x=3.40 ; S D=0.84)$, manuals that teach how to do things $(x=3.39$; SD $=0.86)$, general and specific reference sources $(x=3.30$; SD $=0.94)$ biographical events or individuals $(x=3.23$; SD $=1.02)$ and stimulating works of poetry $(x=3.05 ; S D=0.90)$. The respondents were less interested in natural science related books such as physics, chemistry and biology $(x=1.86 ; S D=1.00)$, followed by political stories, political events and politically related writings $(x=2.18 ; S D=1.22)$, local community events or stories $(x=2.49 ; S D=1.15)$, technology related subject areas, feats and happenings $(x=2.5 I ; S D=1.10)$, detective stories $(x$ $=2.52 ; \mathrm{SD}=1.02)$ general sporting events, sports personalities and sports reports $(x=2.54 ; S D=1.06)$ and social science related books and materials $(x=2.54 ; S D=0.87)$. For the secondary school respondents, their reading interest was strong in the areas of arts related subjects such as history, literature, languages etc $(x=3.27 ; S D=0.84)$, reference sources $(x=3.04$; $S D=1.06)$, manuals that described how to do things $(x=3.04$; $S D=0.95)$, followed by animal stories or stories on specific kind of animals, stories about family life and about families and school related challenges and activity stories with mean and standard deviation scores $(x=2.91$; $S D=1.06) ;(x=2.91$; $S D=1.01) ;(x=2.86 ; S D=$ I.00) respectively. However, the students' least areas of reading interest include natural science books such as physics, chemistry and biology $(x=1.52 ; S D=0.91)$, stories about unreal scientific events/science fiction $(x=1.80 ; S D=0.98)$; and tales of war or about wars $(x=2.10$; SD $=1.04)$. The other areas are historical fiction describing unreal events, mysterious stories with no cause or origin and poems for leisure and class work $(x=2.33$; $S D=1.10) ;(x=2.47$; $S D=$ I.I0); $(x=2.5 \mathrm{I} ; \mathrm{SD}=1.16)$ respectively. This result reveals that respondents in the study are generally not interested in reading science related books and materials or science fiction materials. This can be explained by the fact that information bearing materials for visually impaired persons are very weak in capturing details in these areas. 
5.2 Information needs of persons with visual impairment in the selected libraries

The study asked the respondents their information needs. They were to respond to prepared information need areas. The result showed expectedly that a majority of the respondents $270(91 \%)$ need information on blind and partially sighted educational issues while 252 (84.8\%) were interested in general health information. The need for information on inclusion and equity issues for the visually impaired was expressed by $248(83.5 \%)$ of respondents. The need for current affairs was also high $215(72.4 \%)$ while information on social sciences was demanded by an appreciable 191 (64.3\%) of the respondents.

Other information need areas which recorded high response rates were employment and job opportunities information with 173 (58.2\%) respondents and local area/community information 160 (54\%). Politics and government related information was the only area that recorded a low demand from the respondents.

For the secondary school users, high information needs were recorded in almost all the information need areas. Career related information had 103 (99\%); health information 99 (95.2\%), information about persons with visual impairment and their activities 98 (94.2\%), tertiary education admission information 90 (86.5\%) and current affairs 80 (77\%). The respondents also showed a demand for arts related subjects information and commercial subjects information, each with $64(61.5 \%)$ responses respectively. School activities information had 61 (58.7\%) while politics/ government information were demanded by $35(53 \%)$ of the respondents. The only information need areas with low response score was science/science related subject information with 14 (13.5\%).

Table 3 Information needs of adult persons with visual Impairment in Nigeria $(n=297)$

\begin{tabular}{|l|l|l|l|}
\hline $\mathbf{S} / \mathbf{N}$ & Information need areas & Frequency & $\%$ \\
\hline I. & Blind \& partially sighted education information & 270 & 91 \\
\hline 2. & Health information & 252 & 84.8 \\
\hline 3. & Inclusion \& equity issues for the visually impaired & 248 & 83.5 \\
\hline 4. & Current affairs & 215 & 72.4 \\
\hline 5. & Social services information & 191 & 64.3 \\
\hline 6. & Employment/job related information & 173 & 58.2 \\
\hline 7. & Local area/community information & 160 & 54 \\
\hline 8. & Financial /business information & 158 & 53.2 \\
\hline 9. & Politics/government information & 120 & 40.4 \\
\hline
\end{tabular}

Table 4 Information needs of secondary school persons with visual impairment $(n=104)$

\begin{tabular}{|l|l|l|l|}
\hline $\mathbf{S} / \mathbf{N}$ & Information need areas & Frequency & $\%$ \\
\hline I. & Career related information & 103 & 99 \\
\hline 2. & Health information & 99 & 95.2 \\
\hline 3. & Information about persons with visual impairment and their activities & 98 & $94.2 \%$ \\
\hline 4. & Tertiary education/admission information & 90 & 86.5 \\
\hline 5. & Current ffairs & 80 & 77 \\
\hline 6. & Arts related subjects information & 64 & 61.5 \\
\hline 7. & Commercial related subject information & 64 & 61.5 \\
\hline 8. & School related activities information & 61 & 58.7 \\
\hline 9. & Politics/government information & 55 & 53 \\
\hline 10. & Science and science related information & 14 & 13.5 \\
\hline
\end{tabular}

The study found that Braille is the most preferred source of information for persons with visual impairment generally $26 \mathrm{I}$ (58.3\%), followed by talking book or audio recordings materials I 25 (38.2\%). Only I5 (3.4\%) source their information from Large print. The result also showed differences in the most preferred source of information by the adult 
respondents and the secondary school respondents in the study. While the adult respondents showed preference for Braille $125(72.4 \%)$ as their main source of information, the secondary school students preferred talking book/audio recordings materials 55 (53\%). The adults preferred talking books/audio recordings next to Braille 70 (23.6\%) while the secondary school students chosed Braille next to talking book/audio recordings 46 (44.2\%). Both respondents had large print as their least preferred source of information.

Table 5 Sources of information by persons with visual impairment

\begin{tabular}{|l|l|l|l|l|l|l|}
\hline \multirow{2}{*}{ Preferred sources of information } & \multicolumn{3}{|l|}{ Person with visual impairment } & \multicolumn{2}{l|}{ Adults respondents } & \multicolumn{2}{l|}{ Secondary school respondents } \\
\cline { 2 - 8 } & Freq & $\%$ & Freq & $\%$ & Freq & $\%$ \\
\hline Braille & 261 & 58.3 & 215 & 72.4 & 46 & 44.2 \\
\hline Talking books/recordings & 125 & 38.2 & 70 & 23.6 & 55 & 53 \\
\hline Large prints & 15 & 3.4 & 12 & 0.3 & 3 & 2.9 \\
\hline Total & 401 & 100 & 297 & 100 & 104 & 100 \\
\hline
\end{tabular}

Source: field work 2007

\section{Discussion}

This study lends credence to the consensus among authors that the reading interest of persons with visual impairment are similar to those of the sighted, especially in terms of the range of interest areas (Byrne, et al, 1990; Horten and Horten, 1995). Even when the population of persons with visual impairment is not directly homogenous as in this study, their reading interests are similar to their peers who are sighted. In effect, it is instructive to state that reading interest of persons with visual impairment like the sighted also changes overtime, owing to age, status or position attained in life.

The reading interest of adult persons with visual impairment in this study showed that they are mainly interested in religious, business/entrepreneurial materials, entertainment materials, reference sources, manuals, biography and poetry. This is consistent with sighted persons, though this finding is in contrast with Horten and Horten (1995) and Kimmins (1996), in terms of the extent of materials desired. This may be due to differences in education, environmental factors, economic and social status of respondents in these studies.

Interest in religious materials in this study could be due to the dwindling socio-economic realities in Nigeria which has brought persons with visual impairment much closer to spiritual materials as a last resort. They were much less interested in natural science materials, politics and community events. Less interest in natural science material could be because scientific object, symbols, diagrams and information generally have not been well captured by alternative formats. Visually impaired persons may not enjoy politics or political related stories or books because politicians had not made inclusive policies and have continued to relegate persons with visual impairment in the scheme of things. Materials on community or local events may not interest the visually impaired because of the general negative attitudes towards the blind and other visually impaired persons in African communities.

The visually impaired secondary school students who use their school libraries showed high interest in arts related subject areas, reference sources, short stories (Animal, school and family) and sports. This is in conformity with the findings of Bachmutskaya and Yankova (1996) in a study of Russian children but in contrast to Thomason (1993) who reported interest in science fiction among high school students in an American city. Less interest in science related materials by the secondary school visually impaired students could be due to the high demands of transcribing science and technology based materials into alternative formats; hence the general response of low interest in natural science materials and science fictions.

The adult persons with visual impairment showed the expected information needs. Their information needs are in the relevant areas except for politics and government information which may be as a result of government neglect for the visually impaired. This further relegates them and limits their access to all forms of social participation. Their high level of interest in educational issues, health information, inclusion and equity issues for the visually impaired is particularly noteworthy. This indicates that persons with visual impairment anywhere are desirous of functioning as complete humans and that social opportunities should be widened to reach them. The high level of demand shown towards current affairs, social service information, employment/job information, community information and financial matters is an indication that persons with visual impairment aside from being physically challenged, do not want to be objects of deliberate and inadvertent discrimination by the society. 
The secondary school respondents' response with regards to their information needs is consistent with their adult counterpart. The high demand for career information, health information, information about persons with visual impairment and their activities, tertiary educational information, current affairs, arts and commercial subject information, school activities information suggest that the visually impaired students in secondary schools need information which are essentially similar to their counterparts elsewhere. These information needs will help them function as students and essentially improve their knowledge and well-being. This finding is consistent with studies such as Mabawonku (2004) Adetoro (2004) Edem (1993) and Camble (1994). These studies have shown that specific information user groups or interest groups in Nigeria have the appropriate or expected information needs which are necessary to make decisions, solve problems and reduce uncertainty.

The findings with regards to the reading interest and information needs of persons with visual impairment has implication for transcription of information materials to alternative formats (Braille, Audio recording and Large Prints) and the promotion of information for use. Libraries providing information services to persons with visual impairment should provide information based on their reading interest and information needs. This will ensure optimal information utilisation. It is when the reading interest and information needs of person with visual impairment are known that information materials can be transcribed and provided for use based on these areas of need. Persons with visual impairment have been known to use materials that are available and not necessarily those based on the reading interest and information needs.

The sources of information consulted by persons with visual impairment showed that Braille is the most preferred source of information. However, the study further revealed that it is actually the adult respondents who preferred Braille to other sources. Talking books/audio-recordings are the preferred source by the secondary school persons with visual impairment. Preference for Braille has been on decline in favour of talking book/audio recordings among the young in many countries. Studies such as Chartres (1998) and NLB (2002) have confirmed this, though Johnson (1996) and Ryles (1996) have reported preference for Braille in other places, especially as literacy and communication medium.

The stage of onset of a persons' visual impairment also determines his/her preference. Majority of the respondents in this study either became visually impaired as children or had congenital visually impairment. Persons with congenital visually impairment and those who became visually impaired as children have been known to prefer Braille. The student's preference for talking books/audio-recording in this study runs contrary to this. In recent times, there has been a serious decline in the quality and quantity of Braille teachers in Nigeria while interest in audio-recording by the young had been sustained by ease of use and technology hype.

\section{Conclusion and recommendations}

The reading interests of the visually impaired persons surveyed were varied and strong in many areas for adult and secondary school respondents. They also showed the expected information needs which express their needs for survival and becoming functional members of the society. The information sources consulted by both categories of persons with visual impairment are indicative of how age or ones' stage in life can influence the preference for information materials consulted.

Knowledge of reading interest and information needs of persons with visual impairment is crucial to transcription by producers and information provision in Nigerian libraries for persons with visual impairment.

The study therefore recommends that information materials for persons with visual impairment should be provided first and foremost to meet their reading interest and information needs. Transcription of information materials into alternative format should be based on same in order to increase information sources in alternative format in the libraries.

\section{References}

Adetoro, N. 2004. Towards building capacity for sustainable library and information services for the visually challenged in Nigeria. Journal of Association of Libraries for the Visually Impaired, 3(I):54 - 60.

Arditi, A. \& Rosenthal, B. 1998. Developing an objective definition of visual impairment in vision 96: Proceedings of the International low vision conference. ONCE pp. 33I-334 [Online]. http.www.encyclopedia the free dictionary.com/visual impairment. Accessed 16 September 2006.

Atinmo, M.I. 1999. Integrating people with special needs into the information world: strategies for accomplishment. Paper delivered at the $I^{\text {st }}$ annual public lecture, College library FCE (Special) Oyo. November, 23.

Bachmutskaya, I.V. \&Yankova, Z. 1996. Youth library services. Paper presented at the $62^{\text {nd }}$ IFLA General Conference. Beijing; 253 I August 1996 6p. [Online]. http/www.ifla.org/contact/I 4 I-3-E html. Accessed 4 November 2005

Bryne, W.C., Cylke, F.K., Hagle, A.D., Herdon, J.R. \& Perry, H. 1990. Resources and information, international exchange. Journal of Visual Impairment and Blindness, 86: 6.

Camble, E. 1994. Information Seeking patterns of rural development workers in Bornu State, Nigeria. African Journal of Library, Archives and Information Science 2(4):99-106.

SA JnI Libs \& Info Sci 2010, 76(I) 
Canadian National Institute for the Blind. 2005. Visually impaired resource guide. [Online]. http/www.cbc.ca/canadareads/cr/ 2005/literacy html. Accessed 3 I December 2005.

Chartered Institute of Library and Information Professionals (CILIP). 2005. Library and information services for visually impaired people: professional guidance, policy and research. [Online]. http/www.cilip.org.uk/professional. Accessed 31 December 2005.

Chartres, S. 1998. The leisure reading habits of visually impaired people using audio reading services: customer survey, April 1998. Royal National Institute for the Blind. Unpublished report.

Davis, P. 2005. Reading service for the blind: can you imagine not being able to read newspaper or other printed literature? [Online] from http/www.wvia.og/resources/prrs html. Accessed 3I December 2005.

Edem, U.S. 1993. Information needs and information seeking behaviour patterns of journalist in Nigeria. African Journal of Library, Archives and Information Science 3(22): 167-I74.

Eskola, E. 1998. University students information seeking behaviour in a changing learning environment. Information Research 4(2). [Online]. http://www.shef.ac.uk/ is/publications/infres/isic/eeskola.html. Accessed 27 April, 2009.

Fiankor D.K. \& Adams M. 2004. Information seeking behaviour and information use by students of the Department of Information Studies, University of Ghana, Legon, Ghana Library Journal, 16:45-60.

Hopkins, R. 1989. The information seeking behaviour of literacy scholars. Canadian Library Journal, 46(2): I I 3-I I 5.

Horten, G.K. \& Horten, E.K. (1995). Electronic books for the visually impaired: the Norwegian project. [Online]. http/ www.ifla.org/contacts/html. Accessed 4 November 2005.

Johnson, L. 1996. The Braille literacy crises for children. Journal of Visual Impairment and Blindness. May/June. [Online]. http/ www.plexxa.org/papers/index/html. Accessed 4 November 2005.

Kimmins, E.J. 1996. The reading interest of blind and partially sighted boys ages II-I5. M.A. Thesis. Kean College, New Jersey.

Mabawonku, I. 2004. The information needs of artisans: case study of artisans in Ibadan, Nigeria. Lagos Journal of Library and Information Science, 2(2):6I-76.

Moahi, K. M. \& Monau, R.M. 1993. Library and information needs of disabled persons in Botswana. African Journal of Library, Archives and Information Science I (2): I25-132.

National Library for the Blind. 2002. Out of sight but not out of mind. Visually impaired people's perspectives of library and information services. Research Bulletin 6. [Online]. http/www.Nlb uk.org/common/Research) Bulletin /202002doc.html. Accessed 4 October 2005.

Nielson, G.S. 2005. Library services to the homebound elderly in Denmark. Tokyo, Japanese school for the rehabilitation of persons with disabilities. [Online]. http.www.jsrpd.jp/index.e html. Accessed 3 I December 2005.

Owen, V. 2000. Library provision for visually impaired in the UK and Canada: National services and international cooperation Alexandria, I2(I2):7|-80.

Oyediran-Tidings, S. 2004. Information needs and seeking behaviour of library users, result from Yaba College of Technology, Lagos, Nigeria. Lagos Journal of Library and Information Science, 2(2):77-88.

Popoola S.O. 1996. The information seeking patters and utilization of senior civil servants in the Office of Governor, Ibadan, Oyo State, Nigeria. Nigerian Libraries, 30( I \&2):32-43.

RNIB. 2006. Making your teaching inclusive: what is visual impairment? [Online]. http//www.open.ac.uk/inclusive teaching/pages/ understanding and awareness/what. Accessed 18 February 2009.

Ryles, R. 1996. The impact of Braille reading skills on employment, income, education and reading habits. Journal of Visual Impairment and Blindness, May/June. [Online]. http/www.plexxa.org/papers/index/html. Accessed 4 November 2005.

Shahzard K. 2007. Information seeking behaviour of government college university teachers: a survey. Unpublished Masters Dissertation, University of Punjab, Lahore. Pakistan

Tahir, M., Mahmood. K. \& Shafique, F. 2008. Information needs and information seeking behaviour of arts and humanities teachers: a survey of the University of the Punjab, Lahore, Pakistan. Library Philosophy and Practice. [Online]. http:// www.webpages.uidaho.edu/ mbolin/tahir-mahmood-shafique.pdf. Accessed 5 January 2009.

Thomason, N. 1993. Survey reveals truths about young adult readers. New Mexico: Research report 143.

Watson-Boone, R. 1994. The Information needs and habits of humanities scholars. Research Quarterly, 34(2):203-216. 